K. Bhavani Shankar MBBS MD, H. Moseley FFARCS, V. Vemula MBBS, DA, Y. Kumar MBBS MD DA

\title{
Physiological dead space during general anaesthesia for Caesarean section
}

\begin{abstract}
The physiological dead space and its components were determined during general anaesthesia for Caesarean section in seventeen patients and compared with similar values for seventeen patients undergoing abdominal hysterectomy under general anaesthesia. The physiological dead space was smaller in the pregnant patients, due to a smaller alveolar dead space. The anatomical dead space was similar in both groups. A iowered physiological dead space suggests that there will be a decrease in the pulmonary ventilation perfusion ratio (Vi $\dot{Q})$ during Caesarean section; this could result from better perfusion of the ventilated alveoli than in the mon-pregnant group, due to the increased cardiac output of pregnancy. An improvement in alveolar perfusion should also produce more efficient carbon dioxide elimination in pregnant patients, when compared to non-pregnant subjects.
\end{abstract}

Pregnancy is associated with physiological changes such as increased cardiac output, haemodilution and increased pulmonary ventilation. ${ }^{1}$ The increase in pulmonary ventilation has been shown to produce higher than normal arterial oxygen tensions during pregnancy. ${ }^{2}$ It has been further suggested that the changes in ventilation, cardiac output and haemodilution result in better matching of ventilation and perfusion during pregnancy, ${ }^{3}$ which could reduce the physiological dead space.

The arterial to end-tidal carbon dioxide tension difference (a-E) $\mathrm{PCO}_{2}$ representing alveolar dead space has been shown to be smaller during anaesthesia for Caesarean section than during general anaesthesia in non-pregnant females. ${ }^{4,5}$ Further, the (a-E) $\mathrm{PCO}_{2}$ difference has been found to be reduced in the puerperal period for several days following delivery of the baby. ${ }^{6}$ This therefore implies that the physiological dead space could

\section{Key words}

ANAESTHESIA: obstetric, general; LUNG: physiological dead space.

From the Department of Anacsthesia and Intensive Care, University of West Indies, Queen Elizabeth Hospital, Barbados, where correspondence should be addressed to: Dr. Shankar. also be reduced during Caesarean section, as compared to non-pregnant subjects.

There is only one study in the literature which has evaluated the physiological dead space during general anaesthesia for Caesarean section. ${ }^{7} \mathbf{A}$ mean value for $V_{D} / V_{T}$ of $0.32 \pm 0.03$, was found after correction for apparatus dead space and 0.35 after applying a correction factor for volume measurement. These values are higher than the previously quoted values for physiological dead space ratio $\left(\mathrm{VD}_{\mathrm{D}} / \mathrm{V}_{\mathrm{T}}\right)$ in pregnant women at 38 weeks of gestation, ${ }^{8}$ and in pregnant women in labour, ${ }^{9}$ as shown in Table I. Therefore our study was designed to estimate the physiological dead space in women at Caesarean section (pregnant group) and, for comparison in non-pregnant women, under general anaesthesia (control group).

\section{Methods}

Seventeen patients undergoing elective abdominal hysterectomy formed the non-pregnant control group while the study group comprised 17 patients undergoing elective or emergency Caesarean section. All patients were nonsmokers and none had respiratory or cardiac abnormalities. None of the patients were obese according to the usual weight and height indices. The study was approved by hospital ethics committee and informed consent was obtained from all patients.

The patients in the non-pregnant group received meperidine $1.0 \mathrm{mg} \cdot \mathrm{kg}^{-1}$ and promethazine $0.5 \mathrm{mg} \cdot \mathrm{kg}^{-1} \mathrm{IM}$ one hour before surgery. Induction was achieved with thiopentone $5 \mathrm{mg} \cdot \mathrm{kg}^{-1}$ IV and the patients were intubated with a cuffed endotracheal tube after $1.5 \mathrm{mg} \cdot \mathrm{kg}^{-1}$ succinylcholine IV. Anaesthesia was maintained with 50 per cent oxygen in nitrous oxide, 1 per cent halothane, meperidine supplements IV for additional analgesia when required and relaxation with pancuronium $0.08 \mathrm{mg} \cdot \mathrm{kg}^{-1}$.

All patients in the pregnant group were given $30 \mathrm{ml}$ of magnesium trisilicate* and before surgery were placed in a left lateral tilt sufficient to cause an obvious visual displacement of the uterus to the left. After preoxygena-

*At the time of the study, it was the practice in our hospital to use magnesium trisilicate as antacid before Caesarean section, but now it has been replaced with sodium citrate. 
TABLE I Published values of physiological dead space ratio in pregnant women. All values are corrected for apparatus dead space

\begin{tabular}{ll}
\hline Authors & $V_{0 / V_{T}}$ \\
\hline $\begin{array}{l}\text { Templeton \& Kelman } \\
38 \text { weeks gestation }\end{array}$ & 0.20 \\
$\begin{array}{l}\text { Fischer \& Prys-Roberts } \\
\text { lst stage of labour }\end{array}$ & 0.19 (SD 0.06) \\
$\begin{array}{l}\text { During extradural block } \\
\text { During extradural block and } \\
\text { uterine contraction }\end{array}$ & 0.21 (SD 0.05) \\
$\begin{array}{l}\text { One hour after delivery of the baby } \\
\text { Lyons \& Tunstall? } \\
\text { During Caesarean section } \\
\text { During Cacsarean section, with } \\
\text { volume correction }\end{array}$ & 0.27 (SD 0.06) \\
\hline
\end{tabular}

tion for five minutes, anaesthesia was induced with $5 \mathrm{mg} \cdot \mathrm{kg}^{-1}$ of thiopentone followed by succinylcholine $1.5 \mathrm{mg} \cdot \mathrm{kg}^{-1}$ and the trachea was intubated with a cuffed tube while cricoid pressure was applied. Anaesthesia was maintained with a mixture of 50 per cent oxygen in nitrous oxide with 0.5 per cent halothane and pancuronium $0.08 \mathrm{mg} \cdot \mathrm{kg}^{-1}$ used to maintain relaxation. After the delivery of the baby, anaesthesia was maintained with 50 per cent oxygen in nitrous oxide and meperidine $1.0 \mathrm{mg} \cdot \mathrm{kg}^{-1}$. Non-rebreathing artificial ventilation was maintained in both groups with a Seimens-Elema Servo ventilator $(900 \mathrm{~B})$, fitted with a Seimens carbon dioxide analyser (930). The minute volume was $100 \mathrm{ml} \cdot \mathrm{kg}^{-1}$ $\mathrm{min}^{-1}$ and the respiratory rate was $12 \cdot \mathrm{min}^{-1}$. Expiratory minute volumes ( $V_{E}$ ) were read from the ventilator. The carbon dioxide production per minute $\left(\mathrm{VCO}_{2}\right)$, as well as end-tidal carbon dioxide concentration $\left(\mathrm{FECO}_{2}\right)$ were obtained from the digital output of the $\mathrm{CO}_{2}$ analyser at the time of drawing arterial blood. The calibration of the expiratory flow meter of the ventilator was checked with Wright's respirometer before each case. We chose 50 per cent nitrous oxide in oxygen because the accuracy of the Seimens flowmeter is best at this composition. ${ }^{10}$ The carbon dioxide analyser was calibrated with known concentrations of carbon dioxide before each case.

$\dot{\mathrm{V}} \mathrm{CO}_{2}$ and $\mathrm{FECO}$ were corrected for errors resulting from (a) variations of humidity, (b) internal compliance of the breathing circuit, (c) analyser delay and (d) presence of 50 per cent nitrous oxide in the anaesthetic mixture. ${ }^{10}$ The $\dot{V}_{E}$ was corrected to body temperature and pressure (BTPS) using a correction factor to account for variations in the humidity. ${ }^{10} \mathrm{We}$ derived $\mathrm{FeCO}_{2}$ from $\mathrm{VCO}_{2}$ and $\dot{V}_{E}{ }^{11}$

Arterial blood was taken from a radial artery 25 minutes after anaesthetic induction in both groups, as well as just before the uterine incision in the pregnant group. The samples were analysed for $\mathrm{PCO}_{2}$ immediately in a Coming blood gas analyser (165/2) after two point calibration at $37^{\circ} \mathrm{C}$. The blood gas results were corrected for the temperature difference between the subject and the measuring electrode using the nomograms of Kelman and Nunn. ${ }^{12}$

Physiological dead space (VD) was calculated using the equations of Fisher and Prys-Roberts ${ }^{9}$ and Nunn and Hill. ${ }^{13}$ The anatomical dead space was estimated according to the Bohr's equation (Nunn 1977). ${ }^{14}$ The values were corrected for apparatus dead space which was $20 \mathrm{ml}$. We used the equation of Nunn and Hill (1960); ${ }^{13}$ (a-E) $\mathrm{PCO}_{2} / \mathrm{PaCO}_{2}$, to estimate alveolar dead space (fraction of end-tidal gas coming from unperfused alveoli).

Student's paired t test was used to evaluate the statistical significance between the variables within groups and the unpaired $t$ test was used for comparing between groups. Multiple regression analysis was performed between the dependent variable $\mathrm{VD}(\hat{\mathrm{Y}})$ and the independent variables tidal volume as $\left(X_{1}\right)$, age as $\left(X_{2}\right)$, and weight as $\left(X_{3}\right)$. Regressed values of $V_{D}$ for each subject in the two groups were calculated using respective multiple regrcssion equations. The means of the regressed values (corrected $V_{D}$ ) among the two groups were compared using Student's t test.

\section{Results}

The mean ( \pm SEM) ages and weights in the non-pregnant group were $26.5 \pm 1.09 \mathrm{yr}$ and $76.2 \pm 3.6 \mathrm{~kg}$ and for the pregnant group were $24 \pm 0.7 \mathrm{yr}$ and $83.1 \pm 3.5 \mathrm{~kg}$ respectively ( $\mathrm{P}=$ NS between the two groups). The results of the study are presented in Table II. There were no significant differences between pre- and post-delivery values of various parameters shown in Table II in the pregnant group except for $\mathrm{PaCO}_{2}, \mathrm{PECO}_{2}$ and $\dot{\mathrm{V}} \mathrm{CO}_{2}$. They were lower after delivery than before delivery. The values for physiological dead space ratio $\left(V_{D} / V_{T}\right), V_{D}$ and alveolar dead space were significantly lower in the pregnant group than in the non-pregnant group.

The results of multiple lincar regression between $V_{D}(Y)$ and $V_{T}\left(X_{1}\right)$, age $\left(X_{2}\right)$ and weight $\left(X_{3}\right)$ in the two groups were as follows: non-pregnant group: $Y=0.72$ $\mathrm{X}_{1}-2.81 \mathrm{X}_{2}-0.63 \mathrm{X}_{3}-104.38, \mathrm{r}=0.92(\mathrm{p}<0.001)$. Pregnant group: $Y=0.64 X_{1}-5.96 X_{2}-2.38 X_{3}+$ $32.06, \mathrm{r}=0.86(\mathrm{p}<0.001)$. When $V_{\mathrm{D}}$ was corrected for $\mathrm{Vr}$, age and weight in the two groups using respective multiple regression equations, it was found to be significantly lower in the pregnant group than in the nonpregnant group (Table II).

\section{Discussion}

The physiological dead space ratio (VD/VT) in our nonpregnant subjects undergoing abdominal hysterectomy was $0.37 \pm 0.02$. This is similar to values in healthy adult patients undergoing general anaesthesia reported by Nunn et al. $(0.36),{ }^{15}$ and Heidenstierna and McCarthy (0.38). ${ }^{16}$ 
TABLE II Mean values for $\mathrm{V}_{\mathrm{r}}, \mathrm{VD}_{\mathrm{D}}, \mathrm{V}_{\mathrm{D}} / \mathrm{V}_{\mathrm{T}}$, anatomical dead space, al veolar dead space, $\mathrm{PaCO}_{2}, \mathrm{PECO}_{2}$ and $\mathrm{CO}_{2}$ output (mean $( \pm \mathrm{SEM})$

\begin{tabular}{|c|c|c|c|c|c|c|}
\hline & \multirow[b]{2}{*}{$\begin{array}{l}\text { Non-pregnunt group } \\
n=17\end{array}$} & \multicolumn{5}{|c|}{ Pregnant group $n=17$} \\
\hline & & $\begin{array}{l}\text { Predelivery } \\
\text { (Pre-d) }\end{array}$ & $\begin{array}{l}\text { Pre d w } N P \\
p\end{array}$ & $\begin{array}{l}\text { Post-delivery } \\
(\text { Post-d })\end{array}$ & $\begin{array}{l}\text { Post } d \text { qs NP } \\
p\end{array}$ & $\begin{array}{l}\text { Pre-d vs Post-d } \\
\text { p }\end{array}$ \\
\hline $\operatorname{Vr}(\mathrm{ml})$ & $674.41 \pm 26.83$ & $789.70 \pm 30.70$ & $<0.01$ & $778.29=32.29$ & $<0.05$ & NS \\
\hline $\mathrm{VD}(\mathrm{ml})$ & $255.17 \pm 20.41$ & $201.36 \pm 20.08$ & $0.1-0.05$ & $209.85 \pm 22.91$ & $0.1-0.05$ & NS \\
\hline$V \mathrm{r}\left(\mathrm{ml} \cdot \mathrm{kg}^{-1}\right)$ & $8.99 \pm 0.33$ & $9.48 \pm 0.31$ & NS & $\dagger$ & $\dagger$ & $\dagger$ \\
\hline $\left.\mathrm{VD}(\mathrm{m}] \cdot \mathrm{kg}^{-1}\right)$ & $3.37 \pm 0.23$ & $2.46 \pm 0.28$ & $<0.05$ & $\dagger$ & $\dagger$ & $\dagger$ \\
\hline VD corrected $(\mathrm{ml})^{*}$ & $255.18 \pm 18.82$ & $201.36 \pm 17.20$ & $<0.05$ & $t$ & $t$ & $t$ \\
\hline VD/VT & $0.37 \pm 0.02$ & $0.25 \pm 0.02$ & $<0.001$ & $0.27 \pm 0.02$ & $<0.01$ & N5 \\
\hline VD anatomical & $156.89 \pm 19.72$ & $194.96 \pm 17.13$ & NS & $184.86 \pm 14.03$ & NS & NS \\
\hline VD alveolar & $0.19 \pm 0.01$ & $0.01 \pm 0.02$ & $<0.001$ & $0.03 \pm 0.03$ & $<0.001$ & NS \\
\hline $\mathrm{PaCO}_{2}(\mathrm{kPa})$ & $3.41 \pm 0.07$ & $3.83 \pm 0.09$ & $<0.001$ & $3.34 \pm 0.08$ & NS & $<0.001$ \\
\hline $\mathrm{PECO}_{2}$ & $2.75 \pm 0.09$ & $3.76 \pm 0.07$ & $<0.001$ & $3.22 \pm 0.09$ & $<0.001$ & $<0.001$ \\
\hline $\mathrm{CO}_{2}$ oulput $\left.(\mathrm{m}) \cdot \mathrm{min}^{-1}\right)$ & $168.43 \pm 6.72$ & $271.18 \pm 11.43$ & $<0.001$ & $229.92 \pm 10.11$ & $<0.001$ & $<0.001$ \\
\hline
\end{tabular}

*VD corrected for $V_{r}$, age and weight using mulriple regression equations

+Values could not be calculated due to variation in the weight following delivery of the baby.

During anaesthesia for Caesarean section the physiological dead space ratio was $0.25 \pm 0.02$ before delivery and $0.27 \pm 0.02$ after delivery. These values are close to those obtained by Fisher and Prys-Roberts during extradural block analgesia in pregnant women in labour and those obtained one hour after delivery. ${ }^{9}$ The $\mathrm{PaCO}_{2}$ and $\mathrm{PECO}_{2}$ were lower following the delivery due to a significant reduction in $\mathrm{CO}_{2}$ production, compared to the predelivery state

The physiological dead space ratio $(\mathrm{VD} / \mathrm{VT})$ was lower in the pregnant group than in the non-pregnant group. The absolute physiological dead space (VD) was also lower in the pregnant group (Table II). It has been suggested that the absolute physiological dead space which is corrected for tidal volume, age, body build, breathing pattern and respiratory frequency is a better representation of ventilation perfusion status of a patient than the standard ratio (VD/VT) ${ }^{17,18}$ The corrected VD was significantly lower in the pregnant group (pre-delivery) than in the nonpregnant group. We did not consider respiratory frequency and breathing pattern as variables in the regression analysis as they were the same for all subjects studied.

There was no significant difference in anatomical dead space between the two groups. The alveolar dead space was considerably smaller in the pregnant group than in the non-pregnant group. It has been suggested that mixing and distribution of gas in the lungs is more efficient during pregnancy. ${ }^{19}$ The increased cardiac output associated with pregnancy could lead to a better perfusion of the alveoli in the upper parts of the lungs. This would result in a decrease in the number of alveoli with high $V / Q$ ratios (V/Q $>1$ ) contributing to a lowered alveolar dead space, a reduced (a-E) $\mathrm{PCO}_{2}$ difference and more efficient $\mathrm{CO}_{2}$ excretion in the pregnant group. ${ }^{4,20}$ For similar values of $\mathrm{PaCO}_{2}$, the $\mathrm{PECO}_{2}$ was higher in the pregnant group (after delivery) than in the non-pregnant group implying that $\mathrm{CO}_{2}$ excretion is more efficient in the pregnant group. ${ }^{20}$

Anaesthesia for Caesarean section is associated with changing haemodynamics resulting from anaesthetic agents, manipulations of the uterus, variations in compliance and variable amounts of blood loss. ${ }^{21-25}$ Therefore the resulting variations in pulmonary artery pressure could lead to alterations in ventilation/perfusion ratios, resulting in changes in alveolar dead space. ${ }^{20}$ This would probably explain the wider range of physiological dead space observed in the pregnant group $(0.08-0.42)$ than in the non-pregnant group (0.25-0.52).

The value of the physiological dead space ratio ( $V_{D} /$ VT) reported by Lyons and Tunstall ${ }^{7}$ is higher than our values as well as those reported by other authors during pregnancy and labour (Table I) ${ }^{8,9}$ They compared their value to normal non-pregnant values of $V D / V T$ reported by Nunn, Bergman and Coleman, and stated that factors peculiar to pregnancy do not play a role in altering the physiological dcad space during Caesarean section. However, their conclusions have to be viewed cautiously, since they did not have a control group of non-pregnant patients undergoing general anaesthesia for comparison. This may have been an important omission as the reported values of $V_{D} / V_{T}$ in normal healthy adults varies from 0.19 to $0.45 .^{8,9,18,26,27}$ Furthermore, they did not study the components of the physiological dead space during Caesarean section.

We conclude that the physiological dead space is reduced in patients receiving general anaesthesia for Caesarean section, in comparison with anaesthetized non-pregnant patients. The anatomical dead space was similar in both groups but the alveolar dead space was considerably reduced, resulting in a lowered physiological dead space in the pregnant group. 


\section{Acknowledgments}

The authors gratefully acknowledge Dr. P. Seshagiri Rao, $\mathrm{PhD}$, for his assistance in the statistical evaluation of the results. We wish to thank James McCaskie and Roger King, the technicians who calibrated our equipment.

\section{References}

1 Cohen SE. Why is the pregnant patient different? Seminars in Anesthesia 1982; 1:273-81

2 Anderson CJ, James GB, Mathers NP, Smith EL, Walker $J$. The maternal oxygen tension and acid base status during pregnancy. J Obstet Gynaecol Br Commonw 1969; 76: 16.

3 Suavik SB. Pulmonary disease. In: Medical Complications During Pregnancy. Burnow GN, Ferris TF, (Eds.) Toronto: WB Saunders, 1975: 549-57.

4 Shankar KB, Moseley H, Kumar Y, Vemula V. Arterial to end-tidal carbon dioxide tension difference during Caesarean section anacsthesia. Anaesthesia $1984 ; 41$ : 698-702.

5 Burger GA, Datra S. Chantigian RA et al. Optimal ventilation in general anesthesia for Cesarean section delivery. Anesthesiology 1983; 59: A420.

6 Shankar KB, Moseley H, Kumar Y, Vemula V, Krishnan A. Arterial to end-tidal carbon dioxide tension difference during anaesthesia for tubal ligations. Anaesthesia 1987; in press.

7 Lyons G, Tunstall ME. Maternal blood-gas tensions $\left(\mathrm{PAO}_{2}-\mathrm{PaO}_{2}\right.$ ), physiological shunt and $\mathrm{VD} / \mathrm{VT}$ during general anaesthesia for Caesarean section. Br J Anaesth 1979; 51: 1059-62.

8 Templeton A, Kelman GR. Matemal blood gases, $\left(\mathrm{PAO}_{2}-\mathrm{PaO}_{2}\right)$, physiological shunt and $\mathrm{VD}_{\mathrm{D}} / \mathrm{VT}$ in normal pregnancy. Br J Anaesth 1976; 48: 1001-4.

9 Fischer A, Prys-Roberts C. Matemal pulmonary gas exchange. A study during normal labour and extradural blockade. Anaesthesia 1968; $23: 350-6$.

10 Fletcher $R$, Werner O. Nordstrom L, Johnson B. Sources of errors and their correlation in the measurement of carbon dioxide elimination using the Seimens-Elema $\mathrm{CO}_{2}$ analyser. Bt J Anaesth 1983; 55: 177-85.

11 Olsson SG, Fletcher R, Johnson B, Nordstrom L, Prakash $O$. Clinical studies of gas exchange during ventilatory support - a method using the Siemens-Elema analyser. Br J Anaesth 1980; 52: 491-9.

12 Kelmar $G R$ Nunn JF. Normograms for correction of blood $\mathrm{PO}_{2} . \mathrm{PCO}_{2}, \mathrm{pH}$ and base excess for time and temperature. J Appl Physiol 1966; 21: 1484.

13 Nunn JF. Hill DW. Respiratory dead space and arterial to end-tidal $\mathrm{CO}_{2}$ tension difference in anaesthetized man. J Appl Physiol 1960; 15: 383-9.

14 Nurn JF. Applied Respiratory Physiology. London: Butterworths, 1977; p. 217

15 Nunn JF, Bergman NA, Coleman AJ. Factors influencing the arterial oxygen tension during anaesthesia with artificial ventilation. Br J Anaesth 1965; 37: 898-914.

16 Heidenstierna $G, M c C a r t h y$. The effect of anaesthesia and intermittent positive pressure ventilation with different frequencies on the anatomical and alveolar dead space. Br J Anaesth 1975; 47: 847-52.

17 Tanner $J M$. Fallacy of per-weight and per-surface area standards, and their relation to spurious correlation. J Appl Physiol 1949; 2: 1-15.

18 Harris EA, Hunter ME, Seelye ER, Vedder $M$, Whitlock RML. Prediction of the physiological dead space in resting normal subjects. Clin Sci Molec Med 1973; 45: 375-86.

19 De Swiet $M$. Respiratory system. In: Clinical Physiology in Obstetrics. Hytten F, Chamberline $G_{1}$ (Eds). London: Blackwell Scientific Publication, 1980: 79-100.

20 Astrog $V$. Changes in (a-A)CO $\mathrm{CO}_{2}$ difference and pulmonary artery pressure in anesthetized man. J Appl Physiol 1966; 21: 1299-305.

21 Scot $D B$, Lees $M M$, Davie $T$, Slawson $X B$, Kerr $M G$. Observations in cardio respiratory function during Caesarean section. Br J Anaesth 1969; 41: 489-95.

22 Lees $M M$, Scott $D B$, Kerr MG, Taylor $S H$. The circulatory effects of recumbent postural change in late pregnancy. Clinical Sciences 1967; 32: 453-7

23 Scot $D B$. Inferior venacaval occlusion in late pregnancy and its imporance in anaesthesia. Br J Anaesth 1968; 40: $120-8$.

24 Farmen $J V$, Thorpe $M H$. Compliance changes during Cacsarean section. Br J Anacsth 1969; $41: 999-1001$

25 Toldy $M$, Scott $D B$. Blood loss during Caesarean section general anaesthesia. Br J Anaesth 1969; 41: 868-73.

26 Cole $R B$, Bishop JM. Effect of varying inspircd $\mathrm{O}_{2}$ tension on alveolar-anterial $\mathrm{O}_{2}$ tension difference in man. $J$ Appl Physiol 1963; 18: 1043-8.

27 Churchill-Davidson HC. A Practice of Anaesthesia. London: Lloyd-Luke Ltd, 1984: p. 53.

\section{Résumé}

On a déterminé l" espace mort physiologique et ses composantes durant une unesthésie générale pour césarienne chez 17 patientes et on a comparé les valeurs similaires pour 17 patientes subissant une hystérectomie abdominale sous anesthésie générale. L'espace mon physiologique étail réduit chez les patientes enceintes $d u$ fair d' un espace morr alveolaire pius petit. L'espace mort anatomique érait semblable dans les deur groupes. Un espace mort physiologique abaissé laisse entendre qu' il y a une diminution dans le rapport de perfusion-ventilation pulmonaire $(\dot{V} / \dot{Q})$ durant une césarientne; cette réaction pourrait découler d'une meilleure perfusion alvelolaire résultant d'une augmentation du débit cardiaque dans la grossesse. L'amélioration de la perfusion alvéolaire est aussi le résultar d'une excretion plus efficace de gaz carbonique chez les patientes enceintes comparativement aux patientes qui ne sont pas enceintes. 